\section{Klasehodepine og kronobiologi}

\author{
Høy forekomst av søvnforstyrrelser og skiftarbeid er vanlig blant pasien- \\ ter med klasehodepine.
}

Klasehodepine er en primær, episodisk hodepine med samtidig kraniale autonome symptomer. Hodepineanfallene opptrer påfallende regelmessig, noe som har ført til hypotesen om at klasehodepinens patofysiologi er knyttet til kroppens biologiske klokke.

I mitt doktorarbeid har jeg sett på ulike aspekter ved kronobiologi hos klasehodepinepasienter. Vi fant at $60 \%$ av pasientene i Nord-Norge oppga å ha klasehodepineanfall til faste tider på døgnet. Nærmere $80 \%$ hadde over halvparten av anfallene på natten, hyppigst mellom midnatt og klokken fire. $44 \%$ hadde også klasehodepineperioder til faste tider på året. $40 \%$ av pasientene oppfylte DSM-IV-kriteriene for kronisk insomni. $47 \%$ var skiftarbeidere, langt flere enn i den generelle befolkningen.

Vi kartla også fordelingen av foretrukne døgnrytme/søvnmønster og en polymorfi i PER3-genet hos pasienter med klasehodepine. Vi fant ingen forskjeller mellom pasienter og kontrollpersoner. Til sist gjorde vi pupillometri på pasientene utenom hodepineperiode, og fant at de hadde signifikant redusert parasympatisk funksjon til pupillen sammenlignet med kontrollpersoner.

Resultatene viser at svært mange pasienter med klasehodepine sliter med søvn, og at påfallende mange av dem jobber skift. Skiftarbeid kan være en årsak til at den biologiske klokken kommer i utakt med ytre miljøfaktorer. Pupillometrifunnene gir verdifull informasjon om hvilke hypotalamiske kjerner som er involvert i de ulike fasene av sykdommen.

\section{Hilde Karen Ofte}

hkofte@gmail.com

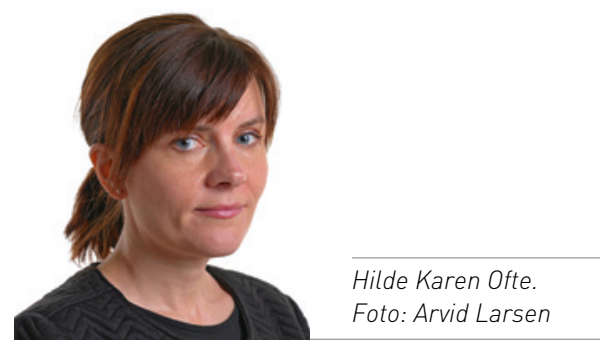

Disputas

Hilde Karen Ofte disputerte for ph.d.-graden ved Universitetet i Troms $\varnothing$ - Norges arktiske universitet 24. oktober 2016. Tittelen på avhandlingen er Hypothalamic clock involvement in cluster headache. A study of chronobiology, sleep and cranial autonomic funcion in cluster headache.

\title{
Psykisk helse hos ekstremt premature barn
}

\begin{abstract}
Barn født ekstremt prematurt har to til åtte ganger høyere risiko for psykiske vansker i både førskole- og skolealder sammenlignet med barn født til termin.
\end{abstract}

På grunn av betydelig bedring av neonatal behandling av ekstremt premature de siste tiårene har mortaliteten sunket betraktelig for disse barna. Mye gjenstår for å kartlegge langtidskonsekvensene.

I mitt doktorarbeid har vi undersøkt en nasjonal populasjon av alle ekstremt premature barn som ble født i Norge 1999-2000, totalt 372 overlevende. Deres psykiske helse ble undersøkt med foreldre- og lærerrapporterte skjemaer ved fem- og 11-årsalder. Utfallet ble sammenlignet med kontrollbarn, som ved fem års alder var alle barn født i 2001 som kom til førskolesjekk i Oppland, totalt 1089 barn. Ved 11-årsalder var kontrollbarna fra Barn i Bergen-prosjektet, det vil si alle barn i Bergen kommune som var 11 år i 2006, totalt 1880 barn.

Forskningen vår viser at ca. én av tre eks- tremt premature barn har psykiske vansker ved førskole- og skolealder, hovedsakelig sosiale, emosjonelle og oppmerksomhetsvansker. Også tvangstanker og -handlinger og hyperaktivitet er hyppigere blant ekstremt premature. Dette er to til åtte ganger hyppigere enn hos kontrollbarna. Ekstremt premature barn med tilleggsvansker som cerebral parese, hørselsvansker, lavere IQ og psykisk utviklingshemning har betydelig $ø k t$ risiko for psykiske vansker.

Våre resultater understreker betydningen av å gi ekstremt premature barn ekstra oppfølging og hjelp i læringssituasjoner og sosiale settinger.

Silje Katrine Elgen Fevang silje_elgen@hotmail.com

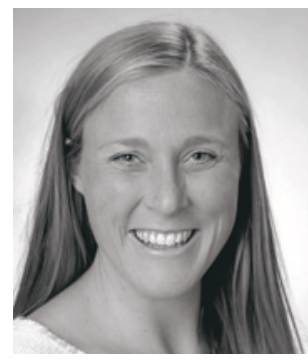

Silje Katrine Elgen Fevang. Foto: Anne Sidsel Herdlevær

Disputas

Silje Katrine Elgen Fevang disputerte for ph.d.-graden ved Universitetet i Bergen 30. september 2016. Tittelen på avhandlingen er Mental health among children born extremely preterm or with extremely low birth weight at preschool-and school age. A national population based study. 